
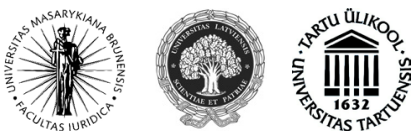

ISSN 1392-6195 (print) ISSN 2029-2058 (online) JURISPRUDENCIJA JURISPRUDENCE 2014, 21(3), p. 847-865.

\title{
BETWEEN CHOICE AND SECURITY: IRRETRIEVABLE BREAKDOWN OF MARRIAGE IN INDIA
}

\author{
Radhika Chitkara \\ National Law University, \\ Sector 14, Dwarka, New Delhi-110078 \\ 01128034257 \\ E-mail: radhika.chitkara@gmail.com \\ Received on 18 May, 2014; accepted on 18 September, 2014 \\ doi:10.13165/JUR-14-21-3-10
}

\section{Introduction}

The debate in India on introducing irretrievable breakdown of marriage as a ground for divorce is indeed an old one. Spurred by contemporaneous developments in the western world, the Delhi High Court in 1971 alluded to the necessity of introducing a no-fault ground of divorce in cases where there is no possibility of cohabitation between the parties ${ }^{1}$. This was the time when marriage in several jurisdictions was undergoing a tectonic shift from being a bond dissoluble only on dereliction of marital duties to a relationship of choice and fulfilment ${ }^{2}$. Taking its cue

1 Ram Kali v. Gopal Das, (1971) ILR 1 Delhi 10.

2 Group Appointed by the Archbishop of Canterbury. Putting Asunder: A Divorce Law for Contemporary Society. London: SPCK, 1966; Law Commission of the United Kingdom. Reform of the Grounds of Divorce: The Field of Choice. 1966; Wardle, L.D. No-Fault Divorce and the Divorce Conundrum. Brigham Young University Law Review. 1991, 1(1): 79; Stark, B. Marriage Proposals: From One-Size-Fits-All to Postmodern Marriage Law. California Law Review. 2001, 89(5): 1479.

Jurisprudencija/Jurisprudence

(C) Mykolo Romerio universitetas, 2014

(C) Mykolas Romeris University, 2014
ISSN 1392-6195 (print), ISSN 2029-2058 (online) http://www.mruni.eu/lt/mokslo_darbai/jurisprudencija/ http://www.mruni.eu/en/mokslo_darbai/jurisprudencija/ 
from these 'modern' developments of re-imagining the marital bond, the 71st Report of the Law Commission of India too opined that "[h]uman life has a short span and situations causing misery cannot be allowed to continue indefinitely".

The debate sparked by no-fault divorce grounds in India adopted the conditions that the UK set for itself in 1965 in its Law Commission Report, The Field of Choice. This was to evolve a model of divorce which "enable[d] the empty shell [of marriage] to be destroyed with the maximum fairness, and the minimum bitterness, distress, and humiliation." Therefore, what originated as a discussion on upholding individual choice and pursuit of happiness gradually evolved into a question of the economic contribution of wives to marriage, and their entitlements to marital property through the introduction of the community of property regime ${ }^{4}$. Even as this discussion was ongoing, the Supreme Court of India, in exercise of its inherent powers, was nevertheless granting divorces on this ground in the absence of legislation.

The four decade long conversation culminated in The Marriage Laws (Amendment) Bill, 2013 [the Bill], recently passed by the Upper House (Rajya Sabha) of the Indian Parliament. It introduces irretrievable breakdown of marriage as a ground for divorce under the Hindu Marriage Act, 1955 and the Special Marriage Act, $1954^{5}$. The passage of the Bill was celebrated as ushering in an era of 'womenfriendly' divorce laws, permitting them greater choice in exiting marriages on the one hand, and also protecting their economic interests on the other. In so doing, the Bill grants women the right to oppose a petition for no-fault divorce on the ground that it will cause her grave economic hardship, and also vests wide discretion in judges to divide property between the spouses. While irretrievable breakdown is not yet legally a ground for divorce ${ }^{6}$, the author of this paper argues that in its current model of asset division, the Bill disappoints in its promise of marital freedom and equality for women.

In Part I, the four decade long debate on no-fault divorce in India with models in other jurisdictions, especially California and the UK, are related. These two jurisdictions have had the most notable influence on divorce law reforms in India. Since California was the focus of the study by Weitzman on the fall in the financial status of women post a no-fault divorce ${ }^{7}$, it significantly moulded the discourse

3 Law Commission of India. 71st Report of the Law Commission of India: The Hindu Marriage Act, 1955- Irretrievable Breakdown of Marriage as a Ground for Divorce. 1978.

4 Agnes, F. His and Hers. Economic and Political Weekly. 2012, 47(17): 10.

5 Family laws in India continue to be governed by distinct religion-based personal laws, applicable to Hindus, Muslims, Christians and Parsis. The Special Marriage Act governs inter-religious marriages and is also an optional regime for those unwilling to submit to their religious laws. The Bill leaves the personal laws of the minorities untouched.

6 The Bill is currently awaiting approval by the Lower House (Lok Sabha) of the Parliament, upon which it will require the further assent of the President of India before it becomes law.

7 See: Weitzman, L.J. The Divorce Revolution: The Unexpected Social and Economic Consequences for Women and Children in America. New York: Free Press, 1985. 
in India, as well. Further, India often turns to legal developments in the UK for evolution in its own law owing to its common law legacy. In both these jurisdictions, introduction of no-fault divorce grounds was accompanied by conditions that protected the economic interests of wives.

In Part II, the simultaneous evolution of no fault divorce jurisprudence by the Supreme Court of India in the absence of legislation is traced. Courts in several cases have granted divorce on the ground of irretrievable breakdown of marriage to render 'complete justice between the parties', without accounting for the concomitant division of property and financial safeguards.

In Part III, the specific provisions of the Bill and its failure to secure economic justice to women within marriages by its refusal of the community of property regime are analysed. While there is a dearth of comprehensive empirical data canvassing the post-divorce finances of women, the author of the paper draws from studies conducted by Kirti Singh ${ }^{8}$ and Jaya Sagade ${ }^{9}$ to analyse patterns of property ownership within families and the post-divorce economic conditions of women in India. These studies arose out of a fault-based divorce regime, but nevertheless sought to secure the rights of wives to marital property. The author of the present paper extrapolates from these studies to argue that the failure to recognise the right of women to marital property under the Bill, and to instead entrust division of property entirely to judicial discretion, operates to the detriment of women and does not ameliorate their 'field of choice' to seek divorce on no-fault grounds.

\section{The Economics of Marriage Recognized?}

The Archbishop's Group in the UK, while drafting the landmark report Putting Asunder to remodel marriage and divorce laws on the ground of no-fault alone, had in focus the consequences of the reforms upon the dependent spouse, inevitably, the wife. Their objective was therefore to model a divorce law that would provide a dignified dissolution of marriage in the most just and equitable manner to the 'innocent' spouse ${ }^{10}$. The subsequent Law Commission Report, The Field of Choice, focused on the same concern, as well. While both disagreed on whether to have only no-fault grounds of divorce, both agreed on the need to secure the economic investment of the wife into the marriage ${ }^{11}$. Since the battle against coverture had

8 See: Singh, K. Separated and Divorced Women in India: Economic Rights and Entitlements. Delhi: Sage Publications Pvt. Ltd., 2013.

9 See: Sagade, J. Law of Maintenance: An Empirical Study. Pune: Indian Law Society, 1996.

10 Group Appointed by the Archbishop of Canterbury. Putting Asunder: A Divorce Law for Contemporary Society. London: SPCK, 1966

11 Kahn-Freund, O. The Law Commission: Reforms on the Grounds of Divorce. The Field of Choice. The Modern Law Review. 1967, 30(2): 181, 185; Levin, J. The Divorce Reform Act 1969. The Modern Law Review. 1970, 33(6): 645; Finlay, H.A. Reluctant, but Inevitable: The Retreat of Matrimonial Fault. The Modern Law Review. 1975, 38(2): 153. 
resulted in a separation of property regime in championing women's economic rights, the UK adopted a division of assets policy, reliant on the discretion of the Courts, in abidance with certain statutory guidelines contained in S.25 of the Matrimonial Causes $\mathrm{Act}^{12}$.

Similarly, the 'divorce revolution' in the USA, triggered by California's conversion into an entirely no-fault divorce regime, simultaneously ushered with it the community of property regime, by which wives were entitled to share in the marital property and the financial benefits of the husband ${ }^{13}$.

New Zealand, Australia and several other states in the USA followed a similar policy, wherein, either through equal division of property, or through equitable division of property, assets of the family were divided between the spouses upon divorce. In Europe, some countries followed a deferred community system, wherein both parties retained ownership of their assets during the marriage, but which were divided upon dissolution ${ }^{14}$.

All these reforms were motivated by the recognition of marriage as an 'economic partnership', with a gendered division of labour. In this division, the wife contributed to the family by tending to the home, the children and the elderly within the family, for which her 'reward' would be to partake in the income and assets of the husband. This division of labour implies that even employed women earn less than their male counterparts, for they are not perceived as primary breadwinners. Often, the wives also compromised on their own career prospects to support the advancement of the husbands. Since it is the husband who mostly engages in economically rewarding activity, the assets would be legally owned by him.

The model of marriage as one fostering economic dependence of the wife upon her husband rings true even more so in the traditional Indian society. Here, marriage is a 'social' institution, and not a question of individual choice. It is mandatory, arranged by families, while rarely parties may choose who to marry. It is treated not merely as a 'sacrament', but as an instrument to provide for the economic security of the woman, whereby the responsibility of the woman is passed from the father to the husband. Regardless of her own employment status, India still treats 'the home' as the exclusive domain of the wife, in return for which the husband is obligated to provide for her. In several ways, the labour of the wife is still 'owned' by the husband, for her labour is expended either as a housewife, or as a 'farmer's wife' tending to

12 Barlow, A. Property and Couple Relationships: What Does Community of Property Have to Offer English Law? Changing Contours of Domestic Life, Family and Law. Oxford: Hart Publishing, 2009, p. 29-32.

13 Kay, H.L. An Appraisal of California's No-Fault Divorce Law. California Law Review. 1987, 75(1): 293.

14 See: Sivaramayya, B. Matrimonial Property Law in India. New Delhi: Oxford University Press, 1999. 
agriculture $^{15}$. For women who work outside the home, they are expected to juggle their domestic duties along with their employment, with scant help from the husbands. Most partners continue to live in joint families, with the parents of the husband. Sometimes, extended branches of the families might also share a roof. In these cases, assets are owned by the eldest male member of the family, but for the benefit of the entire family ${ }^{16}$. Therefore, family is treated as the fundamental unit of society in India even more so than in the West. This raises a bigger demand upon the law to provide for the economic security of women upon a breakdown of the marriage.

While debating irretrievable breakdown in India, women's groups had the benefit of Weitzman's study in California, which exposed the financial hardships that no-fault divorce inflicted upon women ${ }^{17}$. The study itself was widely critiqued and its findings questioned. The main objections to the study was Weitzman's attribution of the fall in the financial status of women to no-fault divorce. Others argued that nofault divorce only exposed the financial equities in the employment sphere that single women had to struggle with absent a man's full income ${ }^{18}$. Nevertheless, Weitzman's solution itself was not a return to a fault-based regime of divorce, but to evolve a more efficient model of economic redistribution between the parties.

It was against this background that women's groups in India demanded a community of property regime, concomitant with the introduction of irretrievable breakdown of marriage as a ground for divorce ${ }^{19}$.

The 71st Report of the Law Commission of India in 1978 considered the merits and demerits of introducing irretrievable breakdown in India and the conditions that should accompany it. While the economic security of women was considered an important issue in the Report, it was couched in the conservative rhetoric of mere 'safeguards'. It was clear that the Law Commission did not accept the marital relationship as an 'economic partnership', calling it instead a 'coalition'.

See: Agarwal, B. A Field of One's Own: Gender and Land Rights in South Asia. Cambridge: Cambridge University Press, 1994.

16 Agnes, F., supra note 4, p. 11.

17 Weitzman, L.J., supra note 7.

18 Singer, J.B. Divorce Reform and Gender Justice. North Carolina Law Review. 1988-1989, 67: 1103-1121; Jacob, H. Another Look at No-Fault Divorce and Post-Divorce Finances of Women. Law and Society Review. 1989, 23(1): 95-116; Gordon, R.M. The Limits of Limits on Divorce. The Yale Law Journal. 1998, 107(5): 1435-1465; Ellman, I.M. Divorce Rates, Marriage Rates, and the Problematic Persistence of Traditional Marital Roles. Family Law Quarterly. 2000, 34(1): 1-42; Melnick, E.R. Reaffirming No-Fault Divorce: Supplementing Formal Equality with Substantive Change. Indiana Law Journal. 2000, 75: 711-729.

19 Agnes, F. Conjugality, Property, Morality and Maintenance. Economic and Political Weekly. 2009, 44(44): 58-59; Agnes, F. Marriage, Divorce and Matrimonial Litigation. Vol. II. New Delhi: Oxford Publications Pvt. Ltd, 2011, p. 61-64; Agnes, F., supra note, p. 11-12; Singh, K., supra note 8, p. 13. 
The family is becoming more democratic and more egalitarian. Both the husband and wife share not only the family house; in some cases they also share the earnings of each other. Because of the rising rate of female activity, the family unit is more of a coalition. It is therefore necessary that if the coalition cannot be worked, the legal sanction must be withdrawn.

The Report presumed marriage to be voluntary coming together of two independent, autonomous, career-oriented individuals, who retain their autonomy and independence even through the marriage, and only 'share' in the resources. While this may be true for a few, select relationships in upper-middle class homes, most marriages are still based on a gendered division of labour within the home ${ }^{20}$.

Through the same lens, the Report also considered no-fault divorces necessary for couples engaged in mutual bickering and fault-finding. The Report did not consider cases of the 'innocent' spouse, in the words of A Field of Choice, that is, cases in which one spouse might resist the divorce. A Field of Choice focused extensively on the middle-aged homemaker, who is deprived of marital benefits for no fault, and for whom divorce laws must provide security ${ }^{21}$.

It was not the first time that the image of the egalitarian marriage was propped in policy-making. Flavia Agnes has previously shed light on the dichotomous perception of a woman in judicial decision-making, where she is viewed as an independent, autonomous being on the one hand, yet her deviation from traditional gender roles is reprimanded in divorce and maintenance proceedings ${ }^{22}$.

On account of this myopic view of the marital relationship, the 71st Law Commission Report also failed to recognise the contribution of the wife in enhancing the career assets of the husband, in which the UK, California and other jurisdictions permit participation by the wife. While the discussion by women's groups did not centre on the pension of the husbands, the Law Commission unilaterally dismissed S.5(3) of the Matrimonial Causes Act as a lottery for the wife. S.5(3) empowers the Court to grant to the wife a share in a benefit which she would have enjoyed had the marriage subsisted.

The rhetoric behind the 'safeguards' was then still oriented towards a minimal, anti-destitution, need-based model, which continues to foster dependency of the wife upon the husband for sustenance post-divorce. The rhetoric did not focus on a division of matrimonial property which would grant the wife certainty and independence post-divorce. Accordingly, the Report made very limited recommendations. Apart from introducing irretrievable breakdown of marriage as a ground for divorce, it recommended that the wife be granted the right to contest the petition on the grounds

20 Agnes, F., supra note 4, p. 11; Singh, K., supra note 8, p. 15.

21 Law Commission of the United Kingdom.

22 Agnes, F. Maintenance for Women: Rhetoric of Equality. Economic and Political Weekly. 1992, 27(41): 2235. 
of grave financial hardship, and to ensure that the dissolution of marriage is preceded by arrangements for the maintenance of children.

Gradually, as the next part bears out, the attitude of the Supreme Court turned the debate into one solely about individual freedom, in blind neglect of the economic entitlements of women. Also, this discourse was modelled on the view of marriage as a union of co-equals, without accounting for the economics of marriage. In the same vein, in Naveen Kohli v. Neelu Kohli ${ }^{23}$, the Supreme Court pressed upon the legislature to urgently introduce no-fault grounds in divorce laws.

Pursuant to this decision, the Law Commission of India suo moto prepared a report on the desirability of introducing irretrievable breakdown of marriage as a ground for divorce in the 217th Report in 2009. It repeated the language of the 71st Report on the need to end the marriage that causes misery to both parties. It recounted the recommendations of Naveen Kohli. It confounded fault grounds with no-fault grounds, by stating in paragraph 2.4, that 'the concept of irretrievable breakdown of marriage cannot be used as magic formula to obtain a decree for divorce where grounds for divorce are not proved.' Yet, it completely obliterated from the debate the need to remodel the economic arrangements within a marriage, and to divide assets upon divorce. The Report did not delve into this aspect of the debate at all! ${ }^{24}$

On this basis, the Marriage Laws (Amendment) Bill, 2010, was introduced in Parliament, carrying the same provisions that the 71st Report of the Law Commission recommended in 1978. Due to protests by women's groups, it was withdrawn and recommended to the Rajya Sabha Standing Committee, which released its 45th Report in $2011^{25}$.

Distinct from the approach of the 71st Report of the Law Commission, which came to its conclusions based on a mere survey among legal professionals, the Standing Committee invited recommendations from lawyers, NGOs and civil society groups. Women's rights groups again reiterated the need for a communion of property model and participation in marital assets, especially the matrimonial home. Further, this was the first time when men's rights groups too presented their proposals. They heavily condemned the financial 'safeguards' contained in the Bill, and proposals for asset division. In their view, these provisions would be misused by women in one-day marriages to arm-twist men into obtaining large divorce settlements!

For the first time, a provision for division of assets was introduced into the law on irretrievable breakdown of marriage, by the Standing Committee, in departure

23 Naveen Kohli v. Neelu Kohli, (2006) 4 SCC 558.

24 Law Commission of India. 217th Report of the Law Commission of India: Irretrievable Breakdown of Marriage- Another Ground for Divorce. 2009.

25 Rajya Sabha Department-Related Standing Committee. Forty Fifth Report on The Marriage Laws (Amendment) Bill, 2010. 2011. 
from the previous Law Commission Reports. It was also for the first time that the economic contribution of women to the marriage was recognised.

[I]t needs to be ensured that the women get their share at least in the assets/ properties which the parties to the marriage have acquired during the subsistence of the marriage. The Committee finds logic in this demand of the various women's organizations. It is generally seen that in majority of cases women are left with very little to fall back upon after the divorce and quite often they also have to bear the burden of the children born out of the wedlock. In such situations, it seems quite natural for women to feel cheated when they are left to their fate without any roof or financial support although during the subsistence of marriage they might have contributed in varied forms in the matrimonial family in the prime of their age... The Committee is strongly of the view that liberalization of the laws of divorce should essentially be accompanied with appropriate provisions recognizing the legitimate rights of the women on the matrimonial property/assets at least, in which they have their share of contribution.

Yet, unlike the Matrimonial Causes Act, the Standing Committee did not specify the factors that determine 'contribution'. However, like the Matrimonial Causes Act, it left the matter entirely to the discretion of the court to determine the appropriate share of the wife in the matrimonial property. In doing so, it left the presumption of separation of property untouched, rejected community of property, but acknowledged the entitlement of wives to matrimonial property to a limited extent. In fact, the Standing Committee viewed the proposal to introduce communion of property as beyond its terms of reference.

Accordingly, the Bill now contains a provision which empowers the Court to make a discretionary division of matrimonial assets upon no-fault divorce. Yet, the background debate on the law makes it clear that at each level policy-makers have merely inched ground in making economic provisions for women. At a time when divorce laws are making a radical shift from fault to no-fault, policy-makers were unwilling to undertake the same radical shift in their evaluation of marital property laws.

\section{The Economics of Marriage Ignored?}

Even while the introduction of irretrievable breakdown of marriage through legislation was contentiously debated, primarily over concern for the economic security of women, the Supreme Court and various High Courts were granting divorce on this ground.

The case of V. Bhagat v. D. Bhagat marked the beginning of this trend in $1994^{26}$. This case involved highly contentious and acrimonious litigation between the parties, 
in which both had made allegations and counter-allegations of adultery, insanity and cruelty against each other. The case went through several rounds of litigation, until the Supreme Court decreed it a fit ground for dissolution of marriage on the grounds of irretrievable breakdown. In the spirit of no-fault divorce reforms elsewhere around the world, the Court observed that the marriage showed clear signs of a breakdown. The best manner in which the bitterness in the proceedings could be put to an end, instead of deciding the 'faults' of each party, would be on the grounds of irretrievable breakdown. The Court recognised that it was not yet a ground for divorce under the Hindu Marriage Act. Therefore, it invoked its inherent powers under Article 142 of the Constitution of India, which empowers the Supreme Court to pass any decree or order to meet the ends of justice. At the same time, it cautioned that this case should not be treated as precedent to grant divorce on no-fault grounds in a routine manner in the trial courts ${ }^{27}$.

The Supreme Court disregarded its own warning against using V. Bhagat v. D. Bhagat as precedent in several cases thereafter, and continues to do so. By invoking its power under Article 142, the Supreme Court granted divorce on the grounds of irretrievable breakdown of marriage in Romesh Chander v. Savitri ${ }^{28}$, Ashok Hurra v. Rupa Zaveri ${ }^{29}$, Sangamitra Ghosh v. Kajal Kumar Ghosh ${ }^{30}$, among several others. More pertinently, in Naveen Kohli v. Neelu Kohli ${ }^{31}$, the Supreme Court adopted the problematic approach of invoking the grounds of irretrievable breakdown of marriage as well as the fault ground of cruelty in dissolving the marriage. It observed that irretrievable breakdown is not yet a ground for divorce under the Hindu Marriage Act, but that public interest would be better served by severing a tie that only causes misery to both parties. The case launched into spotlight for giving an unequivocal recommendation to the Legislature to urgently introduce no-fault grounds of divorce in the marriage laws.

The invocation of Article 142 and the exercise of the Supreme Court's inherent powers was entirely misplaced. Article 142 encapsulates the equitable jurisdiction of the Supreme Court. This can be invoked only when the strict application of law produces patently pernicious results, and not merely a result that is undesirable $e^{32}$. This jurisdiction can be exercised sparingly, in exceptional situations, and cannot supplant existing legal provisions. It cannot be used to 'build a new edifice where none existed earlier, by ignoring express statutory provisions dealing with a subject and thereby

Ibid.

28 Romesh Chander v. Savitri, (1995) 2 SCC 7.

29 Ashok Hurra v. Rupa Zaveri, AIR 1997 SC 1266.

30 Sangamitra Ghosh v. Kajal Kumar Ghosh, (2007) 2 SCC 220.

31 V. Bhagat v. D. Bhagat, (1994) 1 SCC 337.

32 Basu, D.D. Commentary on the Constitution of India. Vol. 5. Nagpur: LexisNexis Butterworths Wadhwa, 2009, p. 5760. 
achieve something indirectly which cannot be achieved directly ${ }^{33}$. The Supreme Court has itself clarified that Article 142 cannot be invoked to create a legal right which does not already exist legislatively ${ }^{34}$. Dissolving marriages on a ground which is not specified in the exhaustive grounds for divorce under the Hindu Marriage Act and the Special Marriage Act does exactly the opposite. It was in 2009 that the Supreme Court recognised this anomaly and refused to dissolve a marriage under Article 142, in the case of Vishnu Dutt Sharma v. Manju Sharma ${ }^{35}$.

Even if the Supreme Court is empowered under Article 142 to grant remedies of this sort, the Constitution does not extend the same power to the High Courts. Yet, the Supreme Court jurisprudence opened floodgates in the High Courts across the country. For instance, in Sanghamitra Singh v. Kailash Singh ${ }^{36}$, the husband had contracted a second marriage, pursuant to which the first wife had initiated criminal proceedings against him for the offence of bigamy. The husband approached the court for divorce on the ground of irretrievable breakdown of marriage, and in appeal, the Orissa High Court accepted the husband's contention! At the same time, the Calcutta High Court in Rajendra Kumar Jajodia v. Puja Jajodia recognized that only the Supreme Court is vested with equitable jurisdiction under Article $142^{37}$. Contrary precedents from both the Supreme Court and the High Courts have led to an inconsistent and arbitrary practice in appeals.

The most problematic aspect of Naveen Kohli v. Neelu Kohli is its characterization of marriage solely as a relationship of choice, with the object of emotional fulfillment alone. As argued earlier, it ignores the context, in which most marriages in India are solemnized, and their role in providing economic security to women. It repeats the rhetoric that a marriage that causes misery must be terminated immediately. Its blindness to the 'women question' is borne out best by their lack of engagement with critics of no-fault divorce reforms.

Some jurists have also expressed their apprehension for introduction of irretrievable breakdown of marriage as a ground for grant of the decree of divorce. In their opinion, such an amendment in the Act would put human ingenuity at a premium and throw wide open the doors to litigation, and will create more problems then (sic) are sought to be solved ${ }^{38}$.

The core objection had so far been the inadequacy of provisions to secure the economic rights of women upon divorce, and not merely litigiousness. With scant information of the entire debate, the Supreme Court has made sweeping comments

State of Punjab and ors. v. Bakshish Singh, (1998) 8 SCC 222.

34 Teri Oat Estates v. Union Territory, Chandigarh, (2004) 2 SCC 130.

35 Vishnu Dutt Sharma v. Manju Sharma, I (2009) DMC 515 SC.

36 Sanghamitra Singh v. Kailash Singh, AIR 2001 Ori 151.

37 Rajendra Kumar Jajodia v. Puja Jajodia, I (2009) DMC 332 Cal.

38 V. Bhagat v. D. Bhagat, (1994) 1 SCC 337. 
on the necessity of introducing reforms, viewing the delay in the process solely as a failure of legislative will. For the same reason, the Supreme Court makes no comment on the best way to secure the economic rights and entitlements of women upon divorce, and sets up a dangerous precedent in matrimonial litigation.

\section{An Unfine Balance}

The approach of the Supreme Court clearly narrates a story of comparativism out of context. It viewed marriage as a relationship entirely of choice, the free exercise which is obstructed by the law. Accordingly, it imports no-fault divorce reforms to the limited extent that they view both parties in a relationship of equality. This is not often the case in India. It neglects to view marriage as an economic partnership, warranting measures to secure the financial position of women post-divorce, and made no such orders in the exercise of its inherent powers under Article 142. Absent the necessary reforms in ownership of marital property, no-fault divorce increases the economic hardship of women, for whom the marriage continues to be the prime means of sustenance in India.

The Bill, on the other hand, is not entirely blind to this context. While the rhetoric in the Supreme Court jurisprudence, the Law Commission Reports and the Standing Committee pertained to marriages that could otherwise potentially be dissolved by mutual consent, the Bill addresses the hardest cases under no-fault divorce: where divorce on the ground of irretrievable breakdown is resisted by one party. Given the Indian socio-economic context, the Bill in S.3 grants the wife the right to oppose the petition for divorce "on the ground that the dissolution of the marriage will result in grave financial hardship to her and that it would in all the circumstances, be wrong to dissolve the marriage."

The Bill here borrows from S.5 of the Matrimonial Causes Act, 1973, which permits the respondent in a petition alleging five years separation (referring specifically to petitions where both parties do not consent to the divorce) to oppose the divorce in case of 'grave financial or other hardship... and that it would in all circumstances be wrong to dissolve the marriage'. However, it is more difficult for the wife to resist the divorce under the Bill, for the grounds are limited to 'grave financial hardship' alone. S.5 of the Matrimonial Causes Act, 1973 was drafted keeping in mind the 'old housewife', who had invested in the family for long years in the assurance of her husband's old age pension ${ }^{39}$, while viewing marriage as an economic partnership. Therefore, S.5(3) of the Matrimonial Causes Act, 1973 alludes to the loss

39 Freeman, M. Understanding Family Law. London: Thomson Sweet \& Maxwell, 2007, p. 123126; Mason, J.; Bailey-Harris R.; Probert, R. Cretney Principles of Family Law. London: Sweet \& Maxwell Ltd., 2008, p. 117-118; Probert, R. Cretney and Probert's Family Law. London: Sweet \& Maxwell, 2009, p. 175-176; Herring, J. Family Law. London: Pearson, 2013, p. 210-215. 
of chance of acquiring any benefit which she would have otherwise acquired. The 71st Law Commission Report did not view the wife's contribution in the same light and dismissed this provision as merely speculative. Absent the context, the Report presumed that S.5(3) would enable the divorced wife to inherit the ex-husband's property on his death!

The absence of context simultaneously eliminates guidance to the wide discretion of the court in determining what constitutes 'grave financial hardship', such that it would 'in all circumstances be wrong to dissolve the marriage'. The Standing Committee recommended that the phrase 'grave financial hardship' be defined with greater specificity. However, no such specifications are provided currently. It is unclear whether the provision of post-divorce maintenance (regardless of the quantum awarded), or her employability, or her temporary accommodation with her natal family could obviate the hardship. Presumably, the 'compensation' introduced in S.13F in the Hindu Marriage Act and S.28D in the Special Marriage Act, however inadequate, would ensure that a divorce is not refused on grounds of financial hardship, but that arrangements are made to eliminate the hardship.

For this reason, the division of matrimonial property, especially the residence, assumes even more significance. The solution suggested by the Bill is inadequate. First, it excludes the bulk of property that may be owned by the husband, in the form of inherited and inheritable property, from the purview of division, and limits division to the only so-called self-acquired property. While the intent was to prevent women from participating in family property which devolves patrilineally, it excludes property inherited through testamentary instruments, as well. Second, the Bill leaves the entire process of division of property to the untrammelled discretion of the judge. The Matrimonial Causes Act, 1973 specifies factors on the basis of which property may be divided between the parties. Most notably, these include the contributions made by each of them (often the wife) to tending to the home and the family, and the pension of the earning spouse. This division of property regime in the UK was revolutionized after White $v$. White $e^{40}$, in which the economic contribution of the wife to the home was expressly recognised as the basis on which to divide property, and not the minimal needs of the wife ${ }^{41}$.

The division of property regime under the Bill is not founded on a recognition of marriage as an economic partnership, nor does Indian law have the benefit of White $v$. White, both of which could have favourably guided the discretion of the judge. Contrarily, Kirti Singh in her study conducted in 2013 analyses the manner in which judicial discretion has actively harmed the economic interests of separated and divorced women in India.

Singh conducted a survey of 405 women across India to ascertain their economic status post-divorce/separation/desertion and accounted for their income levels, 
maintenance, property ownership and division of assets, return of dowry and stridhan articles, etc. Her findings corroborate the findings of Weitzman (albeit on different grounds of divorce) that women face a drastic fall in their economic position after divorce/desertion/separation.

While Singh analyses the lengthy and biased procedures that in themselves defeat the rights of women to their maintenance amounts, in this paper the author focuses solely on the end results. Singh found that only 54 percent of women actually asked for maintenance during matrimonial proceedings, and only 37 percent of women asked for maintenance for their children, due to ignorance of their entitlement to maintenance. At that time, only 12 women reported being satisfied by the amount they were granted eventually. She found that women without an independent source of income received only 13 percent of their husband's salary for their own sustenance. Women who earned less than Rs.1,000 per month, but whose husbands earned between Rs.5,000 and Rs.56,000, received 11 percent of their husband's salary. Further, women who themselves earned more than Rs.10,000 and whose husbands earned between Rs.100,000 and Rs.250,000 received only 4.5 percent of their husband's salary. Singh specifically reports one case in which the husband earned Rs.56,000 per month, and the wife fought for 17 months to receive a paltry sum of Rs.900 per month only. Even when these amounts are awarded, the women continue to depend on their ex-husbands to actually make these monthly payments, who often do not do so, since there are inadequate enforcement mechanisms ${ }^{42}$.

Singh also reports that in the absence of any law governing division of marital property, the woman does not receive any assets on separation at all. Owing to the structure of families in India, where spouses continue to live in joint families with the parents of the husband, or in close proximity with them, it is the in-laws who have legal ownership of the matrimonial home and several other assets. Singh reports that 59.8 percent of women lived in houses that were acquired by the parents of their husbands. Only 15.3 percent lived in marital homes acquired by themselves or with their husbands. Similarly, while 23 percent of women owned land, only 20.5 percent exercised any control over it, since it remained under the possession and control of their husbands. On the other hand, 161 women reported owning vehicles, out of which 42.8 percent were 'gifted' to their husbands by the parents of the woman in dowry. In 65.3 percent of the cases, these vehicles remained with the husband postseparation. Jewellery, which is an important asset in India, was bought by the parents of the wife in 59 percent of the cases, in dowry, and it was returned in only 27 percent cases after divorce ${ }^{43}$.

At the same time, 98.2 percent of the women who participated in the survey reported that they had full responsibility of the housework, while only 10.4 percent 
of the husbands helped with domestic chores. Only 58.5 percent of the women had gainful employment outside the home, even then earning amounts that were inadequate for their independent sustenance. 62.7 percent of the women reported that their own earning capacities and career opportunities had diminished significantly because of the marriage. Either the husband or the in-laws did not favour an education and career for the woman, or the load of housework was so significant that it compromised their employment opportunities ${ }^{44}$.

Jaya Sagade's study of 1,129 instances of matrimonial litigation under the Hindu Marriage Act, 1955 in Pune, Maharashtra during 1986-1987 also shows similar results. There, the interim maintenance granted to women without children ranged from Rs. 75 to Rs. 300 per month, and to women with children (irrespective of the number) ranged from Rs. 100 to Rs.500 per month. These amounts were awarded not only without accounting for the income of the husband, but were inadequate to meet the bare sustenance needs of women ${ }^{45}$.

This situation exists despite the fairly liberal guidelines governing the award of maintenance under S.23(2), Hindu Adoptions and Maintenance Act. According to these guidelines, maintenance should be awarded keeping in view the 'reasonable wants' of the wife (distinct from needs), the lifestyle and status of the parties during marriage, the income level and property ownership of the husband and also the wife. S.27 of the Hindu Marriage Act further empowers the court to make orders regarding the division of property held jointly by the husband and wife at the time of termination. Despite that, the paltry levels of maintenance and asset division proclaim loudly that judicial discretion is exercised adversely to the interests of women.

This is because the starting point of Courts is to view that the income, assets and property of the husband is his exclusive and separate property, in which the wife has no contribution. The presumption, therefore, is to not deprive the husband of the enjoyment of his property as far as possible. This presumption can be deviated upon only through a conservative exercise to fulfil the needs of the wife.

The Bill largely leaves the presumption of separation of property untouched. While following the approach of the Matrimonial Causes Act in the UK to leave property distribution to the discretion of the court, the Bill problematically omits to provide corresponding guidelines on the manner in which this discretion is to be recognised. While the Standing Committee acknowledged the entitlement of women to marital property on account of their contribution, the Bill instead merely warrants an award of 'compensation...to settle her claims.' The Bill does not answer compensation for what, which claims, and the manner of settling them.

Quite problematically, the Bill re-introduces fault into the litigation, by requiring the Court to inquire into the conduct of the parties to determine whether or not this 
standard is met. This carries the threat of linking the financial hardship to the sexual chastity of the wife, which maintenance laws in India continue to insist upon ${ }^{46}$.

Glendon has argued similarly that the equitable division of property regime in New York, which was instated to award women a higher share in matrimonial property, has fared worse for women than the equal division of property regime in California, where the courts have a more definite formula for asset division ${ }^{47}$.

These studies carry three clear lessons. First, the socio-economic climate in India still instates marriage as the prime source of sustenance for women, such that their breakdown has a disproportionately harsh impact on them. Second, the onus of household work falls disproportionately on women, such that they can reap the benefits of their non-economic contribution to the marriage only as long as it survives, or if the property is redistributed. Third, judicial discretion, especially in the absence of guidelines recognising the contribution of women to the home, childcare, etc., makes women worse off.

Unfortunately, the Bill learns very little from these three lessons. It does not recognise the economic contribution of women to marriage, refuses them an equal share in marital property and grants courts untrammelled discretion in asset distribution.

\section{Conclusions}

Irretrievable breakdown of marriage, on its own, assumes the voluntary union of two equal, autonomous, independent individuals for emotional and sexual companionship. Jurisdictions across the world where no-fault divorce is granted recognise that this is often not the case. Sexual division of labour within the family leads to one party, normally the husband, participating in income- and asset-generating activities, while the other party, normally the wife, tends to the 'home'. The co-operative endeavours of both parties form a family and lead to asset accumulation. Breakdown of a marriage, without concomitant economic redistribution, has an adverse impact on the woman. The prospect of impoverishment makes the exercise of choice to dissolve the marriage more onerous upon them. For this reason, jurisdictions adopt some model of asset redistribution, either through a community of property regime, or through deferred community regime, or through an enlightened discretionary mechanism which serves the needs of both parties' best.

India, throughout its policy debates, did not pierce this veil of equality between parties to the marriage. Despite being a society that is still tradition-bound, one that

46 Ashok Hurra v. Rupa Zaveri, AIR 1997 SC 1266; Agnes, F. Conjugality, Property, Morality and Maintenance, p. 61.

47 Glendon, M.A. Withering Away of Marriage. Virginia Law Review. 1976, 62(4): 663-720; Kay, H.L., supra note 13, p. 298-299. 
has institutionalised marriage to provide for the economic security of women, and one that has strict gendered roles within the home, it nevertheless views marriage in dichotomous ways. While it imagines that parties within a marriage exercise their free will in cohabitation, it does not recognise the capacity of women to contribute to asset generation, and continues to view them as dependants alone.

This perception drove the reforms to introduce irretrievable breakdown of marriage in India. While the Marriage Laws (Amendment) Bill, 2013 does provide for asset redistribution on divorce, it partially adopts the UK model to leave the entire process to the discretion of the Court. Unlike the UK model, however, the Bill provides no guidelines to Courts on the manner in which this discretion needs to be exercised. It provides no indication, despite the clear recommendation of the Standing Committee, that the Court is required to account for the contribution of the wife in the accumulation of assets during the course of the marriage.

This untrammelled discretion, as the studies of Kirti Singh and Jaya Sagde have demonstrated, is exercised in a manner that is blind to the situation of women, leaving them in a struggle to make ends meet. While making the institution that provides economic security to women dissoluble easily than before, in the absence of fault, the Bill fails to erect a framework that could provide women with economic security and independence outside the marriage, as well.

Therefore, the 'field of choice' that no-fault divorce expands in India in fact leaves women the choice between economic insecurity and broken marriages.

\section{References}

Agarwal, B. A Field of One's Own: Gender and Land Rights in South Asia. Cambridge: Cambridge University Press, 1994.

Agnes, F. Conjugality, Property, Morality and Maintenance. Economic and Political Weekly. 2009, 44(44): 58-64.

Agnes, F. His and Hers. Economic and Political Weekly. 2012, 47(17): 10-12.

Agnes, F. Maintenance for Women: Rhetoric of Equality. Economic and Political Weekly. 1992, 27(41): 22332235.

Agnes, F. Marriage, Divorce and Matrimonial Litigation. Vol. II. New Delhi: Oxford Publications Pvt. Ltd, 2011.
Barlow, A. Property and Couple Relationships: What Does Community of Property Have to Offer English Law? Changing Contours of Domestic Life, Family and Law. Oxford: Hart Publishing, 2009, p. 27-47.

Basu, D.D. Commentary on the Constitution of India. Vol. 5. Nagpur: LexisNexis Butterworths Wadhwa, 2009.

Ellman, I.M. Divorce Rates, Marriage Rates, and the Problematic Persistence of Traditional Marital Roles. Family Law Quarterly. 2000, 34(1): 1-42.

Finlay, H.A. Reluctant, but Inevitable: The Retreat of Matrimonial Fault. The 
Modern Law Review. 1975, 38(2): 153173.

Freeman, M. Understanding Family Law. London: Thomson Sweet \& Maxwell, 2007.

Glendon, M.A. Withering Away of Marriage. Virginia Law Review. 1976, 62(4): 663-720.

Gordon, R.M. The Limits of Limits on Divorce. The Yale Law Journal. 1998, 107(5): 1435-1465.

Group Appointed by the Archbishop of Canterbury. Putting Asunder: A Divorce Law for Contemporary Society. London: SPCK, 1966.

Herring, J. Family Law. London: Pearson, 2013.

Jacob, H. Another Look at No-Fault Divorce and Post-Divorce Finances of Women. Law and Society Review. 1989, 23(1): 95-116.

Kahn-Freund, O. The Law Commission: Reforms on the Grounds of Divorce. The Field of Choice. The Modern Law Review. 1967, 30(2): 180-186.

Kay, H.L. An Appraisal of California's No-Fault Divorce Law. California Law Review. 1987, 75(1): 291-319.

Law Commission of India. 217th Report of the Law Commission of India: Irretrievable Breakdown of Marriage Another Ground for Divorce. 2009.

Law Commission of India. 71st Report of the Law Commission of India: The Hindu Marriage Act, 1955 Irretrievable Breakdown of Marriage as a Ground for Divorce. 1978.

Law Commission of the United Kingdom. Reform of the Grounds of Divorce: The Field of Choice. 1966.
Levin, J. The Divorce Reform Act 1969. The Modern Law Review. 1970, 33(6): 632-648.

Mason, J.; Bailey-Harris R.; Probert, R. Cretney Principles of Family Law. London: Sweet \& Maxwell Ltd., 2008.

Melnick, E.R. Reaffirming No-Fault Divorce: Supplementing Formal Equality with Substantive Change. Indiana Law Journal. 2000, 75: 711-729.

Probert, R. Cretney and Probert's Family Law. London: Sweet \& Maxwell, 2009.

Rajya Sabha Department-Related Standing Committee. Forty Fifth Report on The Marriage Laws (Amendment) Bill, 2010. 2011.

Sagade, J. Law of Maintenance: An Empirical Study. Pune: Indian Law Society, 1996.

Singer, J.B. Divorce Reform and Gender Justice. North Carolina Law Review. 1988-1989, 67: 1103-1121.

Singh, K. Separated and Divorced Women in India: Economic Rights and Entitlements. Delhi: Sage Publications Pvt. Ltd., 2013.

Sivaramayya, B. Matrimonial Property Law in India. New Delhi: Oxford University Press, 1999.

Stark, B. Marriage Proposals: From OneSize-Fits-All to Postmodern Marriage Law. California Law Review. 2001, 89(5): 1479-1548.

Wardle, L.D. No-Fault Divorce and the Divorce Conundrum. Brigham Young University Law Review. 1991, 1(1): 79142.

Weitzman, L.J. The Divorce Revolution: The Unexpected Social and Economic Consequences for Women and Children in America. New York: Free Press, 1985. 


\title{
NEGRIZŽTAMAS SANTUOKOS IŠIRIMAS INDIJOJE: TARP PASIRINKIMO IR SAUGUMO
}

\author{
Radhika Chitkara \\ Nacionalinis teisès universitetas, Indija
}

\begin{abstract}
Anotacija. Straipsnyje analizuojamas "priklausomos žmonos" diskursas, pagrindžiantis bütinybę vystyti skyrybu abipusiu sutarimu reformas Indijoje. Pagrindinis moters ekonominio saugumo garantas yra santuoka, tačiau skyrybu atveju sutuoktiniai turi akivaizdžiai nelygias teises. Nevaržomos teismų diskrecijos tęstinumas, grindžiamas precedentu, daro didele žalą žmonos ekonominiams interesams bei suvaržo skyrybu abipusiu sutarimu pasirinkimo laisvę. Daroma išvada, kad sutuoktinių ekonominè lygybè turi būti aiškiai apibrèžta ịstatymais ir tiesiogiai igyvendinama teismu praktikoje.
\end{abstract}

Reikšminiai žodžiai: šeimos teisè, santuoka, Indija, skyrybos abipusiu sutarimu, žmonos ekonominiai interesai, jurisprudencija, teismų diskrecija.

\section{BETWEEN CHOICE AND SECURITY: IRRETRIEVABLE BREAKDOWN OF MARRIAGE IN INDIA}

\author{
Radhika Chitkara \\ National Law University, India
}

Summary. The Upper House of the Indian Parliament has recently approved irretrievable breakdown of marriage as a ground for divorce under the Hindu and secular marriage laws. While the liberalization of divorce upholds individual choice, it has adverse consequences upon women in a society where marriage is the primary source of their economic security. This paper argues that the Bill does not adequately protect the economic interests of women upon divorce. It fails to recognize marriage as an economic partnership, but characterizes the wife as a 'dependant' of the husband, worthy of only discretionary 'compensation'. The paper consists of three parts. The first part relates the four decade long debate on no-fault divorce in India and compares it to the models in California and the UK. It is found out that the discourse underlying the debate is founded on two contradictory premises: first, that a marriage is a voluntary union of two equally autonomous individuals. This is opposed to social realities in India, where marriage is not a voluntary union, and the autonomy of wives is greatly curbed. Second, that the 'autonomous' wives are still punished for abdicating on 'wifely' duties within the home, and viewed as 'unequal dependents' whose independent 
economic contribution to the family is ignored. The debate also neglects the compelling empirical evidence from other jurisdictions, narrating the drastic fall in economic status of wives exacerbated by no-fault divorce. The second part narrates the genderblind jurisprudence of the Supreme Court and High Courts which granted no-fault divorce without any legislative backing or any financial orders for the security of wives, thereby converting the debate on no-fault divorce to one solely on choice, and not on the security of wives. In the third part, the Marriage Laws (Amendment) Bill, 2013, which adopts the model of unrestrained judicial discretion to divide property between spouses, is specifically critiqued. It draws from the studies of Kirti Singh and Jaya Sagade to show that discretion in matrimonial litigation is normally exercised adverse to the interests of women. It concludes by stating that the interests of the Bill to uphold individual choice, and symbolically recognize marriage as a union of equals, would have been better served through a community of property regime, with equal division of marital property.

Keywords: family law, marriage, India, no-fault divorce, economic interests of wife, jurisprudence, judicial discretion.

Radhika Chitkara, Delio nacionalinio teisès universiteto mokslo darbuotoja, Indijos universiteto Nacionalinė teisės mokykla (Bengalüras). Mokslinių tyrimų kryptys: lyčių teisė, konstitucionalizmas, šeimos teisè.

Radhika Chitkara, Research Associate, National Law University-Delhi; B.A., LL.B.(Hons.), National Law School of India University, Bangalore. Research interests: gender, constitutionalism, family law. 